\title{
Tendon Biomineralization
}

\author{
Maciej Pawlikowski* and Piotr Bozecki \\ Department of Mineralogy, AGH University of Science and Technology, Poland
}

*Corresponding author: Maciej Pawlikowski, Department of Mineralogy, Petrography and Geochemistry, AGH University of Science and Technology, Mickiewicza, Poland.

\author{
Received Date: March 25, 2019 \\ Published Date: April 04, 2019
}

\begin{abstract}
Due to understandable difficulties with obtaining research materials from humans, bio mineralogical studies were carried out on chicken and beef tendons. Those were chosen as material where biomineralization phenomena occur in a similar fashion as in human tendons. Tendons that were studied were both young and older, at various ages, located both near their connection with bone and with muscle. In the studies, binocular microscopy, polarizing microscopy, and scanning microscopy with EDS chemical analysis attachment were used. It was concluded that tendons undergo progressive mineralization with age. Its early stages are element -mostly calcium and phosphorus-substitutions into the biological structures of collagen that builds tendons. It develops in areas of tendon microinjuries. That mineralization can be discovered only using precise chemical methods because it's virtually invisible under the microscope, even in great magnifications. In older tendons, especially in places where they connect with bone, but also in muscle areas, the highest level of tendon mineralization with weakly crystalline calcium phosphates of mineralogical properties of hydroxyapatite is observed.
\end{abstract}

Keywords: Tendons; Biomineralization

\section{Introduction}

Literature regarding tendons, methods of examining them [16] and various phenomena observed in torn and treated tendons is very rich [7-37]. Especially numerous and difficult to quote fully is literature regarding different treatment technologies [1,38-59]. There are no articles discussing the issues of tendon mineralization, including phenomena that occur in damaged tendons. We hope to partially fill that void with this publication. Presence of tendon mineralization is connected with damage in the structure of tendon collagen. The damaged spots are particularly susceptible to biomineralization (mineralization of biological structures). Due to electric charges present in those spots, they form so called crystallization centers. Secret tendon mineralization consists of element substitution into the biological structures in damaged spots. This phenomenon results in changes of physical properties of such mineralized tendons. They are less flexible and may be shortened or lengthened, so they do not fulfill their functions properly. Resulting dysfunctions lead to further deformations of biological structures of tendons (and nearby muscles), and often to their further mineralization. During the discussed studies of old tendons, micro-grains of calcium phosphates and carbonates were observed that seriously impeded mobility of tendons, and therefore muscles, and as a consequence, e.g. limbs.
Since more advanced mineralization was found in older tendons, we can assume that the phenomenon may be partially connected with demineralization of the bone where the tendon is attached. Therefore, biomineralization may not affect symmetrical tendons (e.g. in two limbs) in equal measure. Tendon- biomineralization undoubtedly hinders their functioning, contributing to dysfunction of individual muscles and entire organs.

\section{Materials and Methods}

Study material consisted of chicken and beef tendons obtained from a slaughterhouse. Tendons that were used came from older and younger animals (as comparative material). In total, 10 chicken tendons and 10 beef tendons from the area above the knee were studied. Selected samples are shown in Figure 1-4. Due to reduction of the volume of this publication, only selected samples that characterize the observed phenomena best were presented. In this study, a stereoscopic microscope (PZO binocular magnifier, model 3) was used to make a selection of tendons for further study. Selected tendons or their parts were observed using a polarizing microscope with lateral illumination. Observations were carried out with partially crossed polarizers, using magnifications up to $400 x$. In those observations a Motic microscope of Chinese 
production, model 07-100477, was used. Observed phenomena were documented with micrographs. Described observations allowed for another selection of material, to be studied using a scanning microscope with EDS chemical analysis attachment. In those studies, the FEI QUANTA 200 FEG microscope was used. Initial markings were semi-quantitative and revealed areas of higher and lower content of elements. In tendons (in particular parts) where increased levels of elements were observed, spot quantitative chemical analyses were conducted, which were then compiled in tables.

\section{Result}

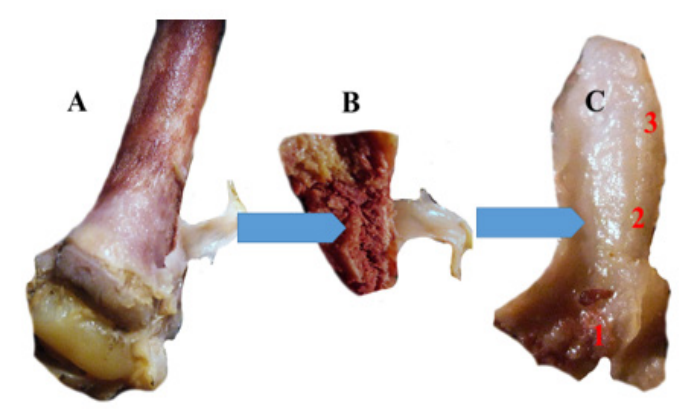

Figure 1: Sample 1. Comparative material - selected young chicken bone with tendons. A - image of the bone with a tendon fragment, $B$ - cross section of the bone in the place of the tendon attachment, $\mathrm{C}$ - tendon with marked places of sampling (red numbers 1-3).
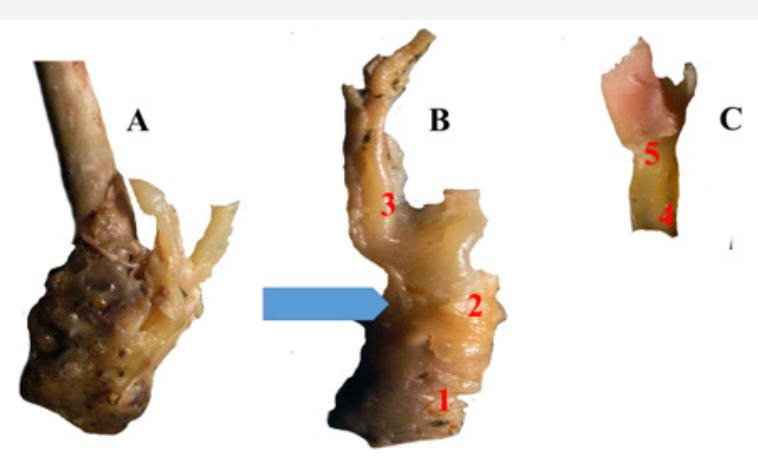

Figure 2: Sample 2. Selected old chicken bone with tendons. Aimage of the bone with a tendon fragment, B - cross section of the bone in the place of the tendon attachment, $\mathrm{C}$ - tendon attached to the muscle. Red numbers - places of sampling (1-5).

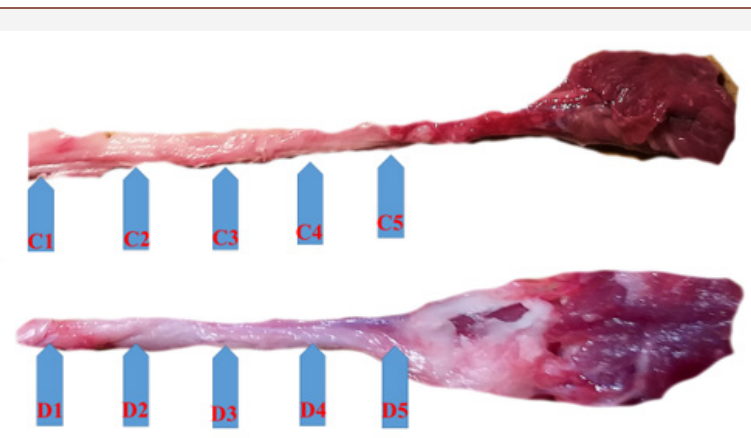

Figure 3: Sample 3C - selected tendon of a young ox. Sample $3 D-$ tendon of an old ox. Muscle going into the beef tendon (knee area). C1-C5, D1-D5 - places of sampling.

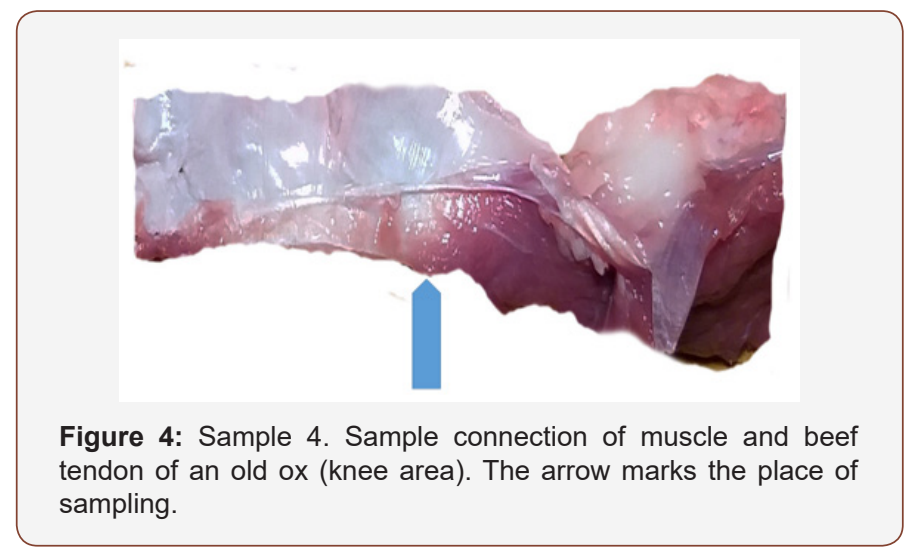

In Figure 1-4 below samples of tendons (selected out of 20) are shown, chosen for detailed tests. Descriptions under the Figures give information regarding the method of sample selection (Figure 1-4).

\section{Selective studies under binocular microscope (magnifier)}

Both in the young and old tendon samples, the areas tested were the tendon-muscle connection, the tendon, and the tendon in the bone attachment area. (Chicken tendons - Figure 5, A-D; beef tendons Figure 6,7 A-D). (Figure 5)

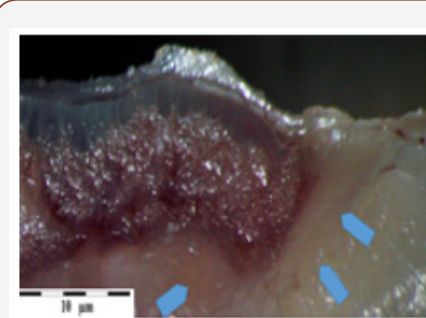

A

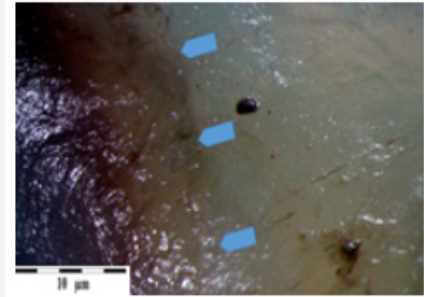

C

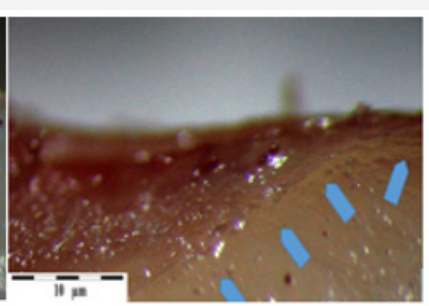

B

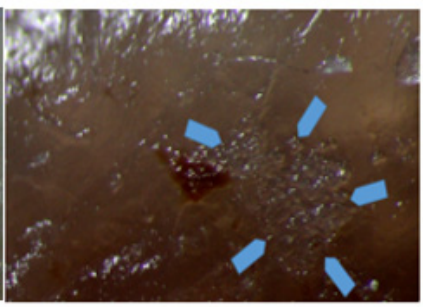

D
Figure 5: Samples 1 and 2 (selected). Chicken tendons. A - muscle-tendon connection (young). B - muscle-tendon connection (old). C, D - tendon near the muscle-tendon connection (old). Arrows show places chosen for detailed studies (SEM-EDS).

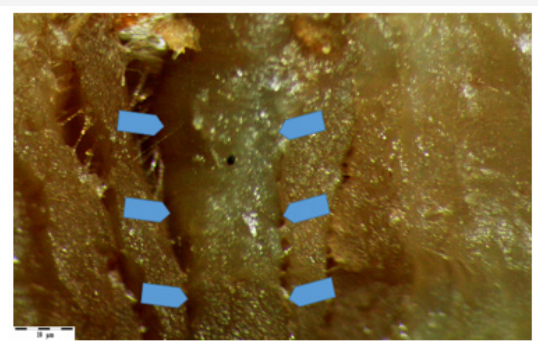

Figure 6: Sample 3C. Place of tendon joint cartilage connection (arrows). Visible subtle detachment of tendon from the cartilage (arrows). 
The connection of the beef tendon with the knee joint cartilage turned out to be interesting Figure 6. Observations indicate that detachment may take place on connection of these two structures. Analyses of the joint cartilage and the tendon itself showed presence of elevated levels of calcium in the collagen in both (Figure 6).

\section{Results of observation: Mineral grains in tendons observed under transmitted light polarizing microscope}

Observations of the tendon structures using polarizing microscope in partially polarized light Figure 7 allowed us to observe a number of places affected by biomineralization. Those places in partially polarized light (incomplete rotation of polarization plane) cause the fragments affected by mineralization to show different interference colors than tendon parts that are not affected by that phenomena Figure 7A, 7B. In some places, mineral grains are observed in the tendon structure Figure7C, 7D.
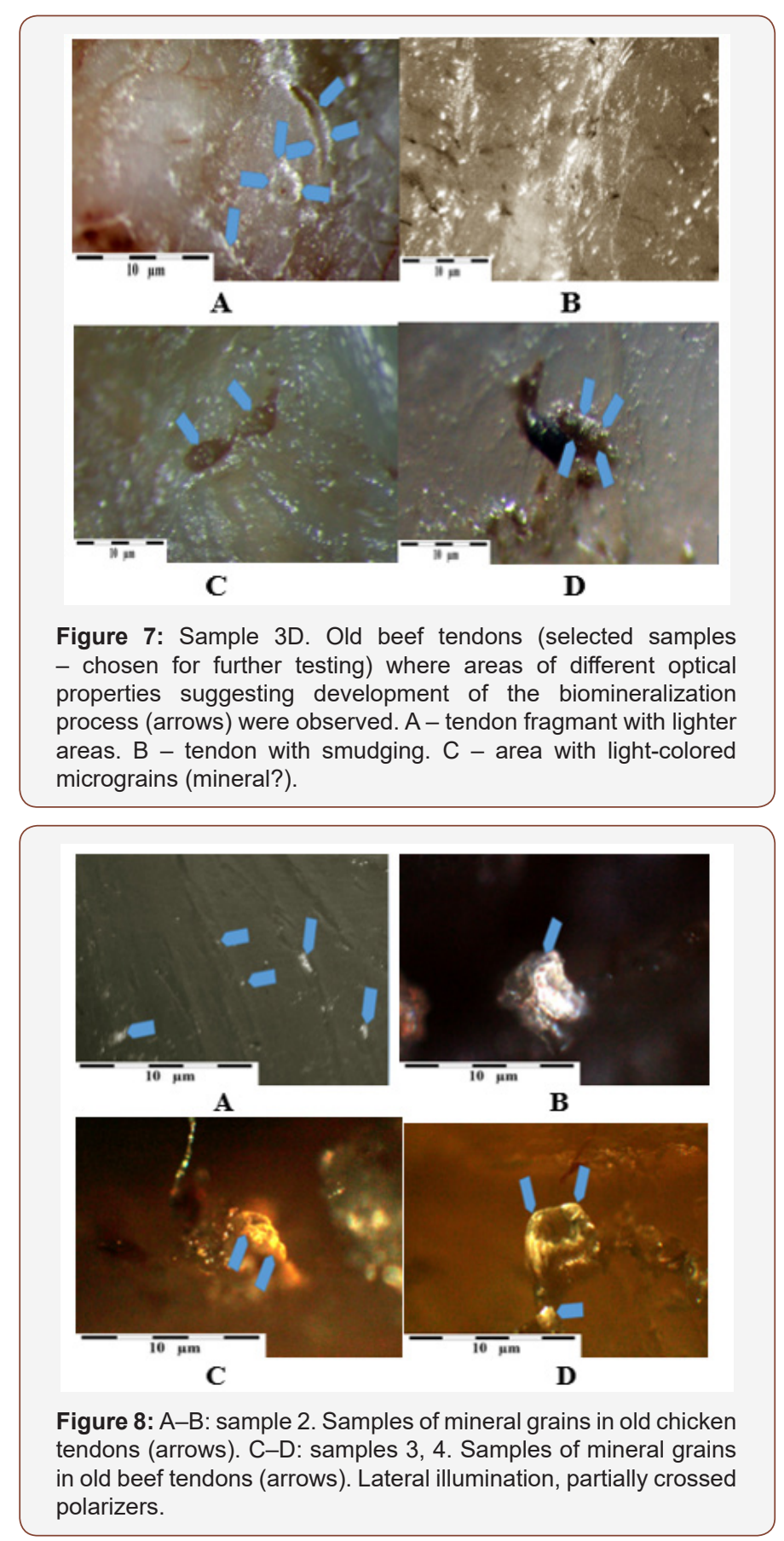

In the studies of tendons using polarizing microscope, particularly interesting were the observations conducted with lateral illumination of the tendons. Despite trouble with obtaining sharpness (small depth of field with higher magnifications) we managed to observe mineral grains in the tendon structure. They are a few micrometers in size and have well developed shapes. Their contents are usually complex, because they consist in part of calcium carbonates or phosphates, and in part of difficult to identify organic substances Figure 8A-8D (Figure 7,8).

\section{SEM-EDS analysis results}

Results of the studies described above allowed for selection of tendon fragments for detailed testing. Both non-mineralized fragments and tendons where mineral concentrations were found were analyzed.

Sample 1. Non-mineralized chicken tendon: Typical test results of one of many tendons are presented below Figure 9. Chemical analyses conducted in many spots of the tendon show only slightly elevated sulfur contents of Table 1 and in some places slightly elevated levels of silica. Only in one spot a grain of silica was observed spot 1 Figure 9, which may be an external surface contamination of the tendon. Observations indicate that in spite of the macroscopic appearance of the tendon not suggesting its mineralization, it contains (like other tendons) elevated, though varied levels of silica and sulfur (Figure $9 \&$ Table 1).

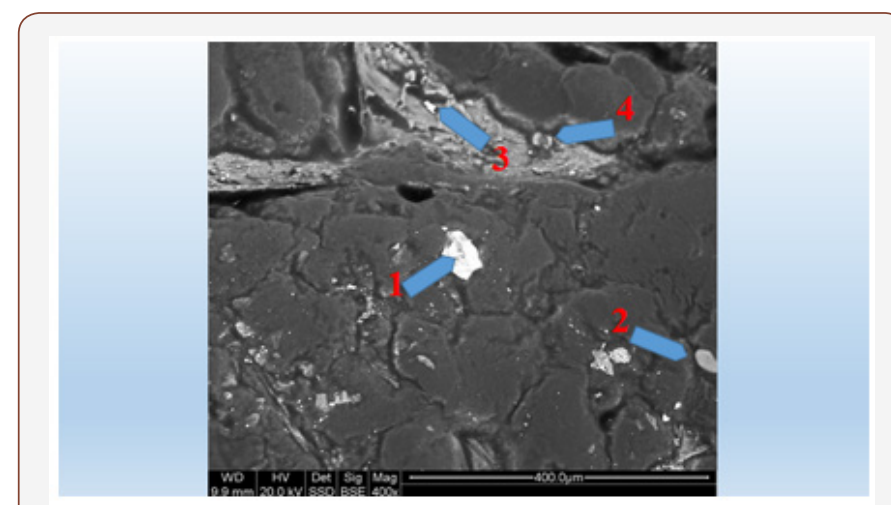

Figure 9: Sample 1-chicken tendon not affected by mineralization (Figure $1 \mathrm{C}$ ). Arrows mark places of chemical analyses (EDS) presented in Table 1.

Table 1: Tabular summary of tendon analysis results in points 1-4 in Figure 9.

\begin{tabular}{|c|c|c|}
\hline Element & Wt \% \\
\hline \multicolumn{3}{|c|}{ Point 2/1 } \\
\hline C & 69.23 \\
\hline O & 21.87 \\
\hline Si & & 8.9 \\
\hline \multicolumn{2}{|c|}{ Point 2/2 } \\
\hline C & \\
\hline O & 75.33 \\
\hline Si & 24.24 \\
\hline S & 0.07 \\
\hline \multicolumn{2}{|c|}{ Point 2/3 } \\
\hline C & 0.36 \\
\hline
\end{tabular}




\begin{tabular}{|c|c|}
\hline 0 & 18.08 \\
\hline $\mathrm{Si}$ & 0.1 \\
\hline $\mathrm{S}$ & 0.32 \\
\hline \multicolumn{2}{|c|}{ Point 2/4 } \\
\hline $\mathrm{C}$ & 91.87 \\
\hline $\mathrm{O}$ & 8.04 \\
\hline $\mathrm{Si}$ & 0.06 \\
\hline $\mathrm{S}$ & 0.03 \\
\hline
\end{tabular}

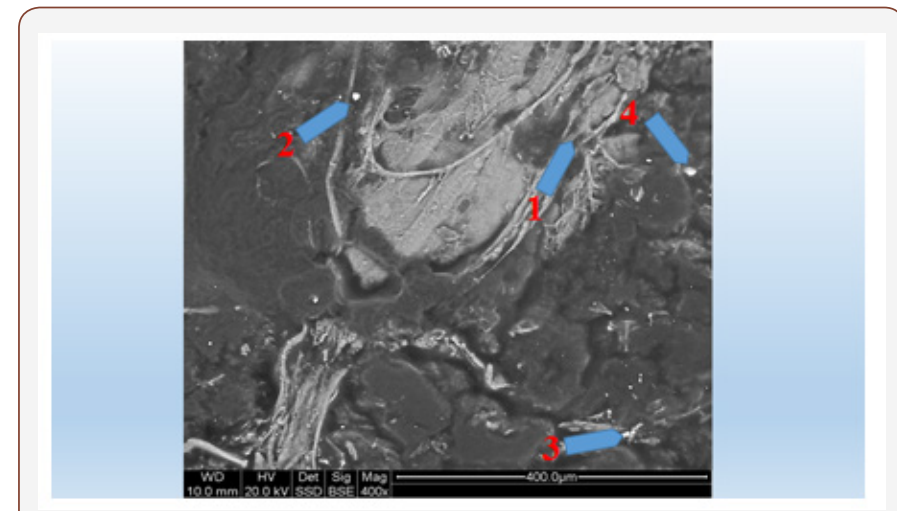

Figure 10: Sample 2. Chicken tendon affected by mineralization (Figure 2 B). Arrows show places where chemical analyses (EDS) presented in table. 2 were conducted.

Sample 3C. Beef tendon not affected by mineralization: In order to compare tendon mineralization in the same spot, the same tests were conducted on beef tendons Figure 11. It turned out that beef tendons that did not look mineralized contained a lot of elements Table 3. However, their presence was not uniform (Figure 11).

Table 2: Tabular summary of tendon analysis results in points 1-4 in Figure 10 .

\begin{tabular}{|c|c|}
\hline Element & Wt \% \\
\hline \multicolumn{2}{|c|}{ Point 2/1 } \\
\hline $\mathrm{C}$ & 86.83 \\
\hline 0 & 12.95 \\
\hline Si & 0.04 \\
\hline$S$ & 0.19 \\
\hline \multicolumn{2}{|c|}{ Point 2/2 } \\
\hline $\mathrm{C}$ & 71.26 \\
\hline 0 & 9.56 \\
\hline $\mathrm{Si}$ & 0.36 \\
\hline$S$ & 0.22 \\
\hline $\mathrm{Fe}$ & 18.6 \\
\hline \multicolumn{2}{|c|}{ Point 2/3 } \\
\hline $\mathrm{C}$ & 86.8 \\
\hline 0 & 5.24 \\
\hline $\mathrm{Na}$ & 0.11 \\
\hline Si & 0.02 \\
\hline S & 0.11 \\
\hline $\mathrm{Cl}$ & 4.19 \\
\hline $\mathrm{K}$ & 3.46 \\
\hline $\mathrm{Fe}$ & 0.08 \\
\hline \multicolumn{2}{|c|}{ Point $2 / 4$} \\
\hline $\mathrm{C}$ & 79.4 \\
\hline 0 & 11.53 \\
\hline $\mathrm{Na}$ & 0.06 \\
\hline $\mathrm{Al}$ & 1.97 \\
\hline $\mathrm{Si}$ & 4.96 \\
\hline S & 0.05 \\
\hline $\mathrm{Cl}$ & 0 \\
\hline $\mathrm{K}$ & 1.89 \\
\hline $\mathrm{Fe}$ & 0.15 \\
\hline
\end{tabular}

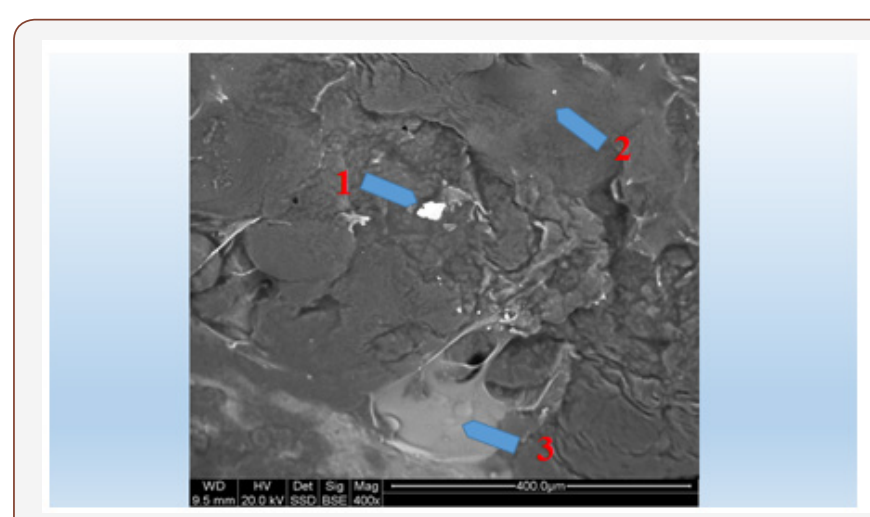

Figure 11: Sample $3(\mathrm{C} 2)$. Beef tendon not affected by mineralization (Figure 3, C3). Arrows show places where chemical analyses (EDS) presented in table. 3 were conducted.

In tendons that do not look as if they are affected by mineralization, areas completely devoid of elements were recognized Point 2, Figure 11, Table 3, point 2. However, there are numerous areas of tendons where many elements are present. (Table 3)

Table 3: Tabular summary of tendon analysis results in points 1-3 in Figure 11.

\begin{tabular}{|c|c|}
\hline Element & Wt \% \\
\hline \multicolumn{2}{|c|}{ Point C2/1 } \\
\hline $\mathrm{C}$ & 45.25 \\
\hline $\mathrm{Na}$ & 32.07 \\
\hline $\mathrm{Mg}$ & 0.09 \\
\hline $\mathrm{Al}$ & 9.32 \\
\hline $\mathrm{Si}$ & 0.1 \\
\hline $\mathrm{S}$ & 12.91 \\
\hline $\mathrm{Cl}$ & 0 \\
\hline $\mathrm{K}$ & 0 \\
\hline $\mathrm{Fe}$ & 0.02 \\
\hline
\end{tabular}




\begin{tabular}{|c|c|}
\hline \multicolumn{2}{|c|}{ Point C2/2 } \\
\hline $\mathrm{C}$ & 89.48 \\
\hline 0 & 10.33 \\
\hline $\mathrm{Na}$ & 0.07 \\
\hline $\mathrm{Mg}$ & 0.05 \\
\hline $\mathrm{Al}$ & 0.02 \\
\hline $\mathrm{Si}$ & 0.02 \\
\hline $\mathrm{s}$ & 0 \\
\hline $\mathrm{Cl}$ & 0 \\
\hline $\mathrm{K}$ & 0 \\
\hline $\mathrm{Fe}$ & 0.05 \\
\hline \multicolumn{2}{|c|}{ Point C2/3 } \\
\hline $\mathrm{C}$ & 79.63 \\
\hline 0 & 18.71 \\
\hline $\mathrm{Na}$ & 0.13 \\
\hline $\mathrm{Mg}$ & 0.07 \\
\hline $\mathrm{Al}$ & 0.11 \\
\hline Si & 0.08 \\
\hline $\mathrm{S}$ & 0.47 \\
\hline $\mathrm{Cl}$ & 0.19 \\
\hline $\mathrm{K}$ & 0.1 \\
\hline $\mathrm{Fe}$ & 0.52 \\
\hline
\end{tabular}

Sample 3 (D5). Beef tendon affected by mineralization: Similar to all the other samples of tendons affected by mineralization, mineralization of tendon on the muscle connection area was observed under the polarizing microscope (Figure 12).

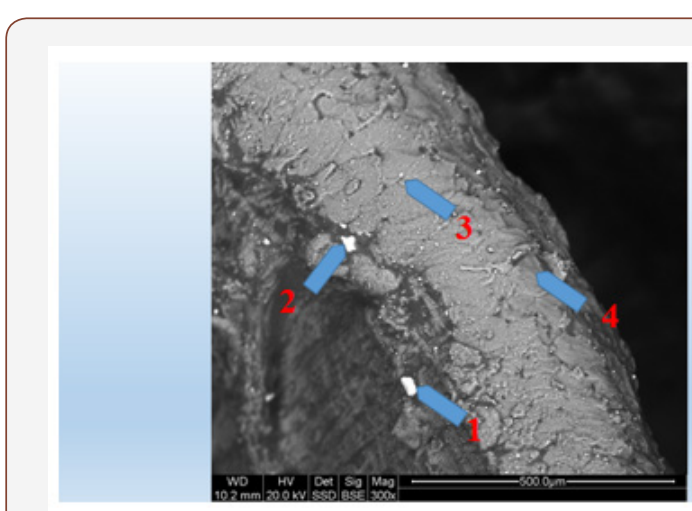

Figure 12: Sample D3 - beef tendon near muscle-tendon connection, affected by mineralization (Figure 3, D5). Arrows show places where chemical analyses (EDS) presented in Table. 4 were conducted. Points 1, 2 are tendon area. Points 3,4 are muscle area.

Conducted chemical analyses indicate that chemical contents of muscle and tendon vary significantly Table 4 . An interesting result is high local content of potassium in a micro-grain found in this tendon sample Table 4, point 1 . In point 2 of this tendon, a micrograin with a high content of silica is present.

In general, analyzed tendons contain more marked elements that are often not present in the muscle. It may be connected with the fact that tendons are built mostly of proteins (collagen) which, unlike muscles, are easily mineralized. The process consists of incorporating minerals into defected protein structures. Perhaps

working tendons are also potentially more susceptible to structural damage than muscles. It is known that such damaged spots become active centers of crystallization. (46) (Table 4)

Table 4: Tabular summary of results of tendon analysis in points 1-2 and muscle analysis in points 3-4 Figure 12.

\begin{tabular}{|c|c|}
\hline Element & Wt \% \\
\hline \multicolumn{2}{|c|}{ Point D5/1 } \\
\hline $\mathrm{C}$ & 46.81 \\
\hline 0 & 13.13 \\
\hline $\mathrm{Na}$ & 0 \\
\hline $\mathrm{Mg}$ & 0 \\
\hline $\mathrm{Al}$ & 0 \\
\hline $\mathrm{Si}$ & 0.07 \\
\hline S & 0 \\
\hline $\mathrm{Cl}$ & 0 \\
\hline $\mathrm{K}$ & 34.52 \\
\hline $\mathrm{Ca}$ & 1.42 \\
\hline $\mathrm{Ti}$ & 1.81 \\
\hline $\mathrm{Fe}$ & 2.23 \\
\hline \multicolumn{2}{|c|}{ Point D5/2 } \\
\hline $\mathrm{C}$ & 43.63 \\
\hline 0 & 26.73 \\
\hline $\mathrm{Na}$ & 0.07 \\
\hline $\mathrm{Mg}$ & 0.09 \\
\hline $\mathrm{Al}$ & 0.38 \\
\hline $\mathrm{Si}$ & 27.9 \\
\hline S & 0.09 \\
\hline $\mathrm{Cl}$ & 0.05 \\
\hline K & 0.19 \\
\hline $\mathrm{Ca}$ & 0.2 \\
\hline $\mathrm{Ti}$ & 0.22 \\
\hline $\mathrm{Fe}$ & 0.44 \\
\hline \multicolumn{2}{|c|}{ Point D5/3 } \\
\hline $\mathrm{C}$ & 81.1 \\
\hline 0 & 18.18 \\
\hline $\mathrm{Na}$ & 0.19 \\
\hline $\mathrm{Mg}$ & 0.06 \\
\hline $\mathrm{Al}$ & 0 \\
\hline $\mathrm{Si}$ & 0.1 \\
\hline S & 0.33 \\
\hline $\mathrm{Cl}$ & 0 \\
\hline $\mathrm{K}$ & 0 \\
\hline $\mathrm{Ca}$ & 0 \\
\hline $\mathrm{Ti}$ & 0 \\
\hline $\mathrm{Fe}$ & 0.04 \\
\hline \multicolumn{2}{|c|}{ Point D5/4 } \\
\hline $\mathrm{C}$ & 36.64 \\
\hline 0 & 34.04 \\
\hline $\mathrm{Na}$ & 0.07 \\
\hline $\mathrm{Mg}$ & 0.2 \\
\hline $\mathrm{Al}$ & 0.15 \\
\hline
\end{tabular}




\begin{tabular}{|c|c|}
\hline Si & 0.28 \\
\hline S & 0.13 \\
\hline $\mathrm{Cl}$ & 0.2 \\
\hline $\mathrm{K}$ & 0.07 \\
\hline $\mathrm{Ca}$ & 0.47 \\
\hline $\mathrm{Ti}$ & 0.14 \\
\hline $\mathrm{Fe}$ & 27.25 \\
\hline
\end{tabular}

Sample 4. Beef tendon affected by mineralization: Due to the observations made on muscle-tendon connections, analyses were also conducted on tendons distant from muscles Figure 13. They were conducted mostly to check potential connection between muscle and tendon mineralization. It was noted that even not too distant spots of one tendon contain different amounts of elements (Figure 13) (Table 5).

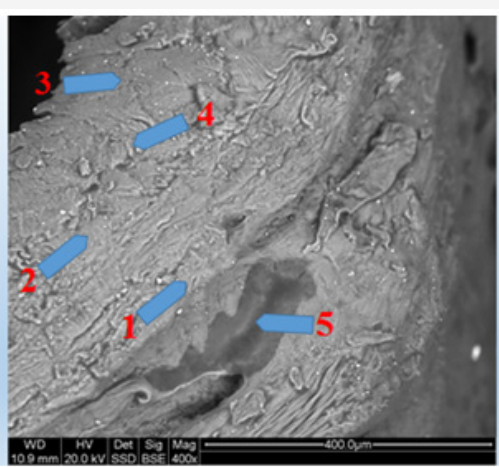

Figure 13: Sample 4- beef tendon affected by mineralization below muscle connection (Figure 4). Arrows show places where chemical analyses (EDS) presented in table 5 were conducted.

Table 5: Tabular summary of results of tendon analysis in points 1-5 in Figure 13.

\begin{tabular}{|c|c|}
\hline Element & Wt \% \\
\hline \multicolumn{2}{|c|}{ Point 4/1 } \\
\hline $\mathrm{C}$ & 76.15 \\
\hline 0 & 23.16 \\
\hline $\mathrm{Na}$ & 0.1 \\
\hline $\mathrm{Mg}$ & 0.05 \\
\hline $\mathrm{Al}$ & 0.09 \\
\hline $\mathrm{Si}$ & 0.11 \\
\hline$S$ & 0.28 \\
\hline $\mathrm{Cl}$ & 0.07 \\
\hline K & 0 \\
\hline $\mathrm{Ca}$ & 0 \\
\hline $\mathrm{Ti}$ & 0 \\
\hline $\mathrm{Fe}$ & 0 \\
\hline \multicolumn{2}{|c|}{ Point 4/2 } \\
\hline $\mathrm{C}$ & 53.35 \\
\hline 0 & 26.78 \\
\hline $\mathrm{Na}$ & 0.27 \\
\hline $\mathrm{Mg}$ & 0.1 \\
\hline $\mathrm{Al}$ & 4.07 \\
\hline $\mathrm{Si}$ & 10.6 \\
\hline
\end{tabular}

\begin{tabular}{|c|c|}
\hline $\mathrm{S}$ & 0.08 \\
\hline $\mathrm{Cl}$ & 0 \\
\hline $\mathrm{K}$ & 4.51 \\
\hline $\mathrm{Ca}$ & 0.03 \\
\hline $\mathrm{Ti}$ & 0.07 \\
\hline $\mathrm{Fe}$ & 0.14 \\
\hline \multicolumn{2}{|c|}{ Point 4/3 } \\
\hline $\mathrm{C}$ & 41.84 \\
\hline 0 & 15.94 \\
\hline $\mathrm{Na}$ & 0.22 \\
\hline $\mathrm{Mg}$ & 0.2 \\
\hline $\mathrm{Al}$ & 0.28 \\
\hline $\mathrm{Si}$ & 0.59 \\
\hline$S$ & 0.44 \\
\hline $\mathrm{Cl}$ & 0.19 \\
\hline $\mathrm{K}$ & 0.11 \\
\hline $\mathrm{Ca}$ & 0.31 \\
\hline $\mathrm{Ti}$ & 0.25 \\
\hline $\mathrm{Fe}$ & 39.63 \\
\hline \multicolumn{2}{|c|}{ Point 4/4 } \\
\hline $\mathrm{C}$ & 76.27 \\
\hline 0 & 23.11 \\
\hline $\mathrm{Na}$ & 0.12 \\
\hline $\mathrm{Mg}$ & 0.02 \\
\hline $\mathrm{Al}$ & 0.04 \\
\hline $\mathrm{Si}$ & 0.08 \\
\hline$S$ & 0.31 \\
\hline $\mathrm{Cl}$ & 0.04 \\
\hline $\mathrm{K}$ & 0 \\
\hline $\mathrm{Ca}$ & 0 \\
\hline $\mathrm{Ti}$ & 0 \\
\hline $\mathrm{Fe}$ & 0 \\
\hline \multicolumn{2}{|c|}{ Point 4/5 } \\
\hline $\mathrm{C}$ & 87.75 \\
\hline 0 & 11.67 \\
\hline $\mathrm{Na}$ & 0.11 \\
\hline $\mathrm{Mg}$ & 0 \\
\hline $\mathrm{Al}$ & 0.04 \\
\hline $\mathrm{Si}$ & 0.05 \\
\hline $\mathrm{S}$ & 0.08 \\
\hline $\mathrm{Cl}$ & 0.05 \\
\hline $\mathrm{K}$ & 0 \\
\hline $\mathrm{Ca}$ & 0.04 \\
\hline $\mathrm{Ti}$ & 0.08 \\
\hline $\mathrm{Fe}$ & 0.13 \\
\hline
\end{tabular}

Those are elements that also mineralize chicken tendons.

\section{Summary and Conclusion}

- Tendons undergo mineralization that consists either of substituting elements into atomic structures of proteins (collagen) or creating phosphate or carbonates micro-grains. 
- Biomineralization of tendons develops in places where biological structures are defected. Those places become centers of crystallization.

- Defects in those structures can be either genetic or developed during the organism's lifetime. Secondary defects are likely connected to the individual's physical activity.

- The medium and source of tendon mineralization are body fluids.

- Tendon biomineralization undoubtedly changes its mechanical properties, which may favor changes in mobility e.g. in joints that are moved by tendons, but also other organs where tendons exist (the spine, intercostal tendons etc.).

- In spite of the studies having been conducted on animal tendons, we can assume that the same phenomena exist in human tendons.

- It appears easier to prevent tendon biomineralization than to remove it, e.g. pharmacologically.

\section{Acknowledgement}

None.

\section{Conflict of Interest}

No conflict of interest.

\section{References}

1. Churchood E (1916) Traumatische Sehnenluxation Eines Fingerstreckers. Beit Klin Chir 102: 743.

2. Li Q, Zhou J, Zhang L (2009) Structure and properties of the nanocomposite films of chitosan reinforced with cellulose whiskers. J Polym Sci 47: 1069-1077.

3. Liu S, Qin M, Hu C, Wu F, Cui W, Jin T, et al. (2013) Tendon healing and anti-adhesion properties of electrospun fibrous membranes containing bFGF loaded nanoparticles. Biomaterials 34(19): 4690-4701.

4. Ishizuki M (1990) Traumatic and Spontaneous Dislocation of Extensor Tendon of the Long Finger. J. Hand Surg 15(6): 967-972.

5. Karthikeyan K, Sekar S, Pandima Devi M, InbasekaranS, Lakshminarasaiah $\mathrm{CH}$, et al. (2011) Fabrication of novel biofibers by coating silk fibroin with chitosan impregnated with silver nanoparticles. J. Mater. Sci. Mater. Med 22(12): 2721-2726.

6. Kettelkamp DB, Flatt AE, Moulds R (1971) Traumatic Dislocation of the Long Finger Extensor Tendon. J. Bone and Joint Surg 53(2): 229-240.

7. Mason ML (1930) Rupture of Tendons of the Hand. Surg Gynecol Obstet 50: 611 .

8. Razemon P (1930) Luxation Traumatique du Tendon Extenseur du Medius. Ann d Anat Pathol 7: 238.

9. Smith RJ (1974) Balanceand Kinetics of the Fingersunder Normaland Pathological Conditions. Clin Orthop104: 92-111.

10. Carroll C, Moore JR, Weiland AJ (1987) Posttraumatic Ulnar Subluxation of the Extensor Tendons: A Reconstructive Technique. J Hand Surg Am 12(2): 227-231.

11. Dohnert MB, Ferreira GK, Silveira PC, Zanoni ET, Dohnert LH, et al. (2015) Inflammatory cytokines content in Achilles tendinopathy after phonophoresis treatment combined with gold nanoparticles and diclophenac diethylammonium in rats. Inflammation 38(3): 1044-1049.

12. Elson RA (1967) Dislocation of the Extensor Tendon of the Hand. Report of a case. J Bone Joint Surg Br 49(2): 324-326.
13. Harvey FJ, Hume KF (1980) Spontaneous Recurrent Ulnar Dislocation of the Long Extensor Tendon so the Fingers. Hand Surg 5: 492-494.

14. IftikharTB, Hallmann BW, Kaminski RS, Ray AK (1984) Spontaneous Rupture of the Extensor Mechanism Causing Ulnar Dislocation of the Long Extensor Tendon on the Long Finger. Two case reports. J. Bone and Joint. Surg Am 66(7): 1108-1109.

15. Koniuch MP, Peimer CA, VanGorder T, Moncada A (1987) Closed Crushed Injury of the Metacarpophalangeal Joint. J Hand Surg. 12(5 Pt 1): 750756.

16. Morohashi M, Sasahara S, Hasegawa M, Ibaragi K (1967) Spontaneous Dislocations of the Extensor Tendon. Orthop Surg (apan) 18: 354-356.

17. Oragui E, Sachinis N, Hope N, Khan WS, Adesida A(2012) The use of nanotechnology in tendon regeneration and repair. J Stem Cells $7(2)$ : 121-126.

18. Ostrowski DM (1989) Traumatic Dislocation of the Long Finger Extensor Tendon at the Metacarpophalangeal Joint. Orthop 12(4): 581-583.

19. Ovesen OC, Jensen EK, Bertheussen KJ (1987) Dislocation to Extensor Tendons of the Hand Caused by Focal Myoclonic Epilepsy. J Hand Surg Br 12(1): 131-132.

20. Pawlikowski M (1987) Mineralization of human living organism). Prace Mineral 79: 121.

21. Pawlikowski M (1993) Crystals of human organism. Secesja. (Atlas): 132.

22. Pawlikowski M (1994) Mineralization of human tissues as effect of ageing). Prace Spec. PTMin 5: 196.

23. Pawlikowski M (1995) Secrets of tissues mineralization. Wyd. IGSMiE PAN Kraków: 97.

24. Pawlikowski M (2003) Minerals in human blood vessels and their dissolution in vitro, In: Skinner HCW, Berger AW, Geology and health. N.Y.-Oxford. Oxford Univ, USA, pp.155-158.

25. Pawlikowski M (2004) Mineralogy and chemistry of osteoporosis mechanism of mineralization (calcification) of human tissues. Prec. Goldschmidt Conf. Kopenhaga: A531.

26. Pawlikowski M (2011) Osteoporosis as source of elements mineralizing tissues. Materiały Konf. Mechanizmy służące utrzymaniu życiai regulacji fizjologicznych. Krakówm: 79-83.

27. Pawlikowski M (2014) Osteoporosis as A Source of Tissue Mineralization. Research on Osteoporosis Therapy and Dissolution of Arterial Mineralization. Jour Life Science 8: 610-625.

28. Pawlikowski M (2016) Biomineralogy of osteoporosis. Acad. J. Biotech 4: 138-144.

29. Pawlikowski M (2017) Centers of Human Tissue Biomineralization (Calcification). Cardiol Cardiovascmed 1: 252-261.

30. Pawlikowski M, Pfitzner R (1995) Mineralogical methods useful for examination of human tissues. Mineralization of heart structures. Przegl Lekarski 52: 24-27.

31. Pawlikowski M, Niedżwiedzki T (2002) Mineralogy of bones. Wyd. PAN Oddział w Krakowie: 128.

32. Pawlikowski M, Niedźwiedzki T, Bieniek A, et al. (2015) Mineralogical testing of femur heads and joint cartilage of patients with avascular necrosis (AVN). In: M Pawlikowski (Ed.) Auxiliary sciences in archaeology, preservation of relicts and environmental engineering CDno 20.

33. Saldana MJ, McGuire RA (1986) Chronic Painful Subluxation of the Metacarpal Phalangeal. Joint Extensor Tendons. J Hand Surg 11(1): 420423.

34. Silfverskiold N (1928) Luxatio Traumatica Subcutanea Tend in Extens Dig. IIIet Luxatio Habitualis Tend.Extens. Dig IV Man Sin Acta Chir Scand 64: 305-310.

35. Straus FH (1940) Luxationof Extensor Tendons in the Hand. Ann Surg 111: 135-140. 212 The Iowa Orthopaedic Journal Ulnar Subluxation of 
the Extensor Digitorum Communis Tendon: A Case Report and Review of the Literature.

36. Tubiana R, Valentin P (1964) The Anatomy of the Extensor Apparatus of Fingers. Surg Clin North Am 44: 897-906.

37. Wheeldon FT (1954) Recurrent Dislocation of Extensor Tendons in the Hand. J Bone and Joint Surg 36(4): 12-617.

38. Araki S, Ohtani T, TanakaT (1987) Acute dislocation of the extensor digitorum communis tendon at the metacarpophalangeal joint. A report of five cases. J Bone Joint Surg Am 69(4): 616-619.

39. Bhattacharyya S, Salvetat JP, Saboungi ML (2006) Reinforcement of semicrystalline polymers with collagen modified single walled carbon nanotubes. Applied Physics Letters 88(23): 233119.

40. Bunnell S (1948) Surgery of the Hand. In: JB Lippincott (Eds.) Philadelphia, London, UK, pp. 670-671.

41. Bunnell S (1964) In Surgery of the Hand. In: JB Lippincott ( $3^{\text {rd }}$ edn.) Philadelphia, London, UK, pp. 470-471.

42. Chen S, Wang G, Wu T, Zhox X, Liu S, et al. (2014) Silver nanoparticles/ ibuprofen-loaded poly (L-lactide) fibrous membrane: anti-infection and anti-adhesion effects. Int J Mol Sci 15(8): 14014-14025.

43. Cutler CW (1942) The Hand: Its Disabilities and Disease. In: WB Saunders (Eds.) Philadelphia, London, UK.

44. Doyle J (1988) Extensor Tendons-Acute Injuries. In Operative Hand Surgery. In: DP Green (Ed.), Churchill Livingstone, New York, USA, pp: 2053-2055.

45. Empson YM, Ekwueme EC, Hong JK, Paynter DM, Kwansa AL, et al. (2014) High elastic modulus nanoparticles: a novel tool for subfailure connective tissue matrix damage. Transl Res 164(3): 244-257.

46. Fitzgerald FF (1939) Habitual Dislocation of the Digital Extensor Tendons. Ann Surg 110(1): 81-83.

47. Haberern JP (1902) Uber Sehnenluxationen. Deutsche Zietsch Chir 62: 191-204.
48. He X, Xiao Q, Lu C, Wang Y, Zhang X, Zhao J, et al. (2014) Uniaxially aligned electrospun all-cellulose nanocomposite nanofibers reinforced with cellulose nanocrystals: scaffold for tissue engineering. Biomacromolecules 15: 618-627.

49. Koniuch MP, Peimer CA, VanGorder T, Moncada A (1987) Closed Crushed Injury of the Metacarpophalangeal Joint. J Hand Surg 12(5 Pt 1): 750756.

50. Kwan KHL, Liu X, To MK, Yeung KW, Ho CM, et al. (2011) Modulation of collagen alignment by silver nanoparticles results in better mechanical properties in wound healing. Nanomedicine 7(4): 497-504.

51. Kwan KHL, Yeung KWK, Liu X, Wong KKY, Shum HC, et al. (2014) Silver nanoparticles alter proteoglycan expression in the promotion of tendon repair. Nanomed. Nanotechnol. Biol Med 10(7): 1375-1383.

52. Longo UG, Lamberti A, Petrillo S, Maffulli N, Denaro V (2012) Scaffolds in tendon tissue engineering. Stem Cells Int 2012: 517165.

53. Lui PP (2015) Stem cell technology for tendon regeneration: current status, challenges, and future research directions. Stem Cells Cloning 11(8): 163-174.

54. Marsh H (1986) Clinical Lecture on Displacements and Injuries to Muscles and Tendons. Brit Med Jl 2: 181.

55. Mc Coy FJ, Winsky AJ (1969) Lumbrical Loop Operation for Luxation of the Extensor Tendons of the Hand. Plast Reconst Surg 44(2): 142-146.

56. Michon J, Vichard P (1961) Luxations Laterals Des Tendons Extenseurs En Regard De L'articulation Metacarpophalangienne. Rev Med De Nancy 86: 595-601.

57. Ritts GD, Wood MB, Engber WD (1985) Nonoperative Treatment of Traumatic Dislocation of the Extensor Digitorum Tendons in Patients without Rheumatoid Disorders. J Hand Surg 10: 714-716.

58. Sahni V, Tibrewal S, Bissell L, Khan WS (2014) The role of tissue engineering in Achilles tendon repair: a review Curr Stem Cell Res. Ther 10(1): 31-36.

59. Thomopoulos S, Parks W C, Rifkin DB, Derwin KA (2015) Mechanisms of tendon injury and repair. J Orthop Res 33(6): 832-839. 